\title{
POLA STRATEGI NAFKAH RUMAHTANGGA PETANI BERBASIS SUMBERDAYA LOKAL DI DESA MANTANGAI HILIR KECAMATAN MANTANGAI
}

\author{
Yuni Erlina ${ }^{1}$
}

ABSTRACT

The objectives of this research are: (1) To examine the pattern of utilization of agricultural resources based on local resources by households as the source of household income. (2) To examine the pattern of livelihood strategy that is determined as the rationality of the decision of the household household in Mantangai Hilir village.

The basic method of research using survey method. The determination of research location was determined purposively in Mantangai Hilir Village, Mantangai District. The aims of the first and second research are analyzed by qualitative approach and described descriptively. The results showed that the pattern of utilization of agricultural resources based on local resources by the households of the farmers are sourced from rubber plantations, wetlands/fiels, yard/other garden, forest land, and swamp and river. The pattern of livelihood strategies in the utilization of local natural resources indirectly implements the cost efficiency principle whereby the livelihood strategy pattern is based on the consideration of the rationality of the household decision of the farmer.

Keywords: Livelihood Strategy, Local Resources, Household Economy.

\section{PENDAHULUAN}

Pola kehidupan petani di pedesaan seringkali dikaitkan dengan sektor pertanian dalam arti luas, dimana kehidupan masyarakat yang tinggal di wilayah tersebut memiliki kecenderungan sikap yang bergantung kepada sumberdaya alam. Petani yang tinggal di wilayah pedesaan dapat berfungsi sebagai produsen dan juga berfungsi sebagai konsumen penghasil produk-produk pertanian, yang tidak luput juga dari berbagai tekanantekanan dalam ekonomi rumahtangganya.

Faktor-faktor kompleks yang dihadapi oleh rumahtangga petani dalam aktivitas usahataninya dapat berkait dengan kondisi alam atau musim, keterbatasan sumber daya manusia, modal, akses terhadap teknologi modern, dukungan terhadap sarana dan prasarana yang masih terbatas dan lain-lain, sehingga petani belum mampu semaksimal mungkin untuk memanfaatkan segenap potensi yang tersedia.

$$
\text { Guna memahami kehidupan }
$$
ekonomi rumahtangga petani di pedesaan, dapat didekati dengan menggunakan pola strategi nafkah (livelihood strategies). Pendekatan tersebut tidak hanya berkait dengan pendapatan dan aktivitas usahatani, namun bagaimana untuk lebih memahami kehidupan rumahtangga, prioritas dalam 
hidup mereka, serta bagaimana membantu mereka agar dapat bertahan hidup. Kasuskasus kerentanan terhadap fluktuasi harga, kerentanan terhadap cuaca atau iklim yang tidak menentu dewasa ini, membuat rumahtangga untuk awas dan mengelola pola struktur nafkah guna meminimalisir resiko yang dihadapi.

Kebutuhan rumahtangga yang kompleks dan adanya kecenderungan jika tidak dapat memenuhi kebutuhan rumahtangga, membuat rumahtangga harus membuat pilihan (choice). Rumahtangga petani dapat memilih alternatif sumberdaya yang dapat mendatangkan manfaat (utility) yang sebesar-besarnya sebagai pemuas kebutuhan rumahtangga, atau menentukan pilihan terhadap penggunaan sumberdaya yang memerlukan pengorbanan yang terkecil diantara berbagai alternatif pilihan dalam memenuhi kebutuhan rumahtangga (Pramutoko, 2012).

Kajian yang berkait dengan pola strategi nafkah ini dilakukan guna lebih memahami pilihan strategis yang dilakukan oleh rumahtangga petani sebagai hubungan antara akses sumberdaya serta aktivitas yang dipengaruhi oleh sistem ekologi dan sosial kemasyarakatan (Ellis, 2000).

Berdasarkan permasalahan diatas penelitian ini bertujuan untuk (1) Mengkaji pola pemanfaatan sumberdaya pertanian berbasis sumberdaya lokal yang digunakan oleh rumahtangga sebagai sumber nafkah rumahtangga.

Menganalisis variabel pola strategi nafkah yang ditentukan oleh pertimbangan rasionalitas keputusan rumahtangga petani di desa Mantangai Hilir Kecamatan Mantangai.

\section{METODE PENELITIAN}

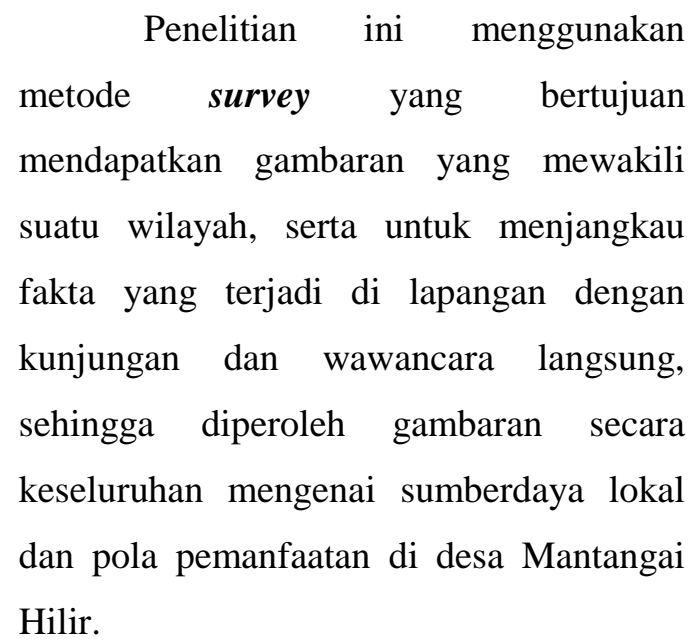

Data yang dikumpulkan terdiri dari data primer dan data sekunder. Penentuan lokasi penelitian ditentukan secara purposive pada Desa Mantangai Hilir Kecamatan Mantangai berdasarkan banyaknya rumahtangga petani $(70 \%$ petani) menggantungkan sumber nafkah hidup pada bidang pertanian dan perkebunan. Penentuan rumahtangga pertanian (RTP) dilakukan dengan cara Simple Random Sampling sebanyak total 58 RTP yang didasarkan atas karakter nafkah rumahtangga, akses sumber nafkah, 
dan aktivitas nafkah rumahtangga, sehingga diharapkan dapat mewakili populasi yang ada. Tujuan penelitian pertama dan kedua dianalisis dengan pendekatan kualitatif dan diuraikan secara deskriptif.

\section{HASIL DAN PEMBAHASAN}

\subsection{Profil Sosial Ekonomi Desa Mantangai Hilir}

Secara administratif desa Mantangai Hilir merupakan salah satu desa yang ada di Kecamatan Mantangai Kabupaten Kapuas, dengan luas wilayah adalah seluas $202,52 \mathrm{~km}^{2}$. Desa Mantangai Hilir pada Tahun 2015 memiliki jumlah penduduk sebanyak 3.542 orang, terdiri dari 992 rumahtangga, dengan kepadatan penduduk sebesar 17,49 jiwa per kilometer, dan rata-rata anggota keluarga per rumahtangga adalah sebanyak 3,57 orang.

Sarana dan prasarana yang dimiliki meliputi prasarana pelabuhan; tempat ibadah berupa Masjid dan Langgar; sarana pendidikan SMPN 1 Mantangai, MIS Ubudiyah Mantangai, MTs Ubudiyah Mantangai, SMA Islam Ubudiyah Mantangai, serta dua buah sekolah dasar negeri; $\quad$ sarana Kepolisian Sektor Mantangai; sarana kesehatan berupa Puskesmas Mantangai, serta sarana ekonomi berupa pasar yakni
Pasar Beringin. Akses jalan dapat dilalui menggunakan jalan darat maupun sungai. Pada bagian hilir atau selatan dari desa Mantangai Hilir terdapat pelabuhan. Pelabuhan ini sejak awal berdirinya jarang digunakan karena jauh dari pemukiman penduduk. Pelabuhan ini sempat juga digunakan sebagai pelabuhan speedboat saat speedboat masih ada trayek dari Kuala Kapuas ke Mantangai.

Aktivitas ekonomi terletak di Pasar Beringin terletak tidak jauh dari Puskesmas Mantangai. Pasar ini beroperasi seminggu sekali pada tiap hari Rabu. Persiapan aktivitas jual beli dimulai sejak Selasa sore, dimana para pedagang sudah berdatangan dari berbagai penjuru untuk mempersiapkan barang dagangan menghadapi hari pasar. Biasanya kapal-kapal dagang akan menumpuk dan berpusat di pelabuhan pasar menurunkan barang-barang yang akan diperdagangkan. Proses transaksi perdagangan tidak berlangsung lama, dari pagi sampai sekitar pukul 10.00 WIB pada hari Rabu.

Fasilitas listrik telah hampir ada hampir pada setiap rumahtangga, meski ada pula rumahtangga yang menyambung listrik dari tetangga lainnya. Setiap rumah memiliki listrik rata-rata dengan kapasitas 450 watt. Listrik digunakan oleh rumahtangga untuk penerangan, penggunaan televisi dan alat elektronik lainnya seperti setrika, megic com dan 
lainnya, serta ada beberapa rumahtangga yang memiliki kulkas yang digunakan untuk membuat es batu untuk dijual atau untuk keperluan rumahtangga.

Fasilitas yang terdapat di dalam rumah penduduk berasal dari usaha masing-masing pemilik rumah, yang diperoleh dari pendapatan rumahtangga. Keberadaan fasilitas yang ada di dalam rumah menunjukkan kemampuan masingmasing rumahtangga untuk memenuhi kebutuhan (non pangan) lebih dari kebutuhan untuk konsumsi pangan.

Sebagian besar kebutuhan konsumsi sehari-hari dipenuhi dari hasil usaha pertanian, serta pertukaran langsung di desa Mantangai Hilir. Pembelian kebutuhan sehari-hari atau kebutuhan barang dagangan untuk pedagang serta kebutuhan untuk aktivitas pertanian seperti bibit, pupuk, serta sarana produksi lainnya yang tidak didapat di desa, dapat dilakukan pembelian di kota kecamatan atau kota Kabupaten terdekat.

Proses pemasaran produk banyak dilakukan di dalam wilayah Desa Mantangai Hilir. Penjualan hasil perkebunan dilakukan melalui pedagang di tingkat desa. Penjualan hasil perkebunan rata-rata dilakukan satu minggu sekali yang dilakukan secara serentak oleh semua petani karet kepada pedagang desa atau pun tengkulak yang masuk ke desa Mantangai Hilir. Hasil-hasil pertanian seperti padi, umbi-umbian, jagung, buahbuahan dan sayur-sayuran ada yang dikonsumsi oleh rumahtangga, namun ada pula yang dijual.

Keadaan status sosial kemasyarakatan dan pelapisan sosial di desa Mantangai Hilir tidak banyak perbedaan yang mencolok dan dianggap rata-rata hampir sama. Berdasarkan hasil penelitian, ada tiga hal yang menjadi dasar penghargaan dalam masyarakat desa Mantangai Hilir yakni (1) penghargaan yang diberikan berdasarkan pekerjaan, (2) penghargaan yang diberikan berdasarkan pendidikan formal dan informal yang dimiliki individu, serta (3) penghargaan yang diberikan berdasarkan kepemilikan barang seperti memiliki perkebunan dan ladang yang luas, memiliki rumah dengan lantai dari keramik atau pun kayu ulin, memiliki kendaraan bermotor serta rumah yang dilengkapi dengan peralatan elektronik. Memiliki kedudukan dalam perangkat desa, keagamaan, ataupun kemampuan menyekolahkan anak sampai ke tingkat perguruan tinggi menempatkan seseorang pada kelas sosial yang lebih tinggi. Kondisi ini dapat ditunjukkan dalam bentuk stratifikasi dalam masyarakat yang ditunjukkan dalam Tabel 1. 
Tabel 1. Dasar Penghargaan dan Jenis Aset di Masyarakat

\begin{tabular}{|c|c|c|c|}
\hline \multicolumn{2}{|c|}{ Dasar Penghargaan } & \multicolumn{2}{|r|}{ Jenis Aset } \\
\hline \multicolumn{2}{|l|}{ Jenis, Kedudukan } & \multicolumn{2}{|c|}{ Status dalam desa } \\
\hline \multicolumn{2}{|l|}{ Jabatan, pendapatan } & \multicolumn{2}{|l|}{ Pekerjaan } \\
\hline \multicolumn{2}{|c|}{ Luas Tanah, Kelas Tanah, Jenis Tanaman } & \multicolumn{2}{|l|}{ Tanah } \\
\hline \multicolumn{2}{|c|}{ Ukuran, model, bahan pembuat } & \multicolumn{2}{|l|}{ Rumah } \\
\hline \multicolumn{2}{|l|}{ Tingkat pendidikan } & \multicolumn{2}{|c|}{ Pendidikan formal dan non formal } \\
\hline \multicolumn{2}{|l|}{ Jenis, ukuran, merek } & \multicolumn{2}{|c|}{ Barang elektronik } \\
\hline \multicolumn{2}{|l|}{ Jenis, jumlah } & \multicolumn{2}{|c|}{ Hewan ternak } \\
\hline \multicolumn{2}{|l|}{ Model, harga } & \multicolumn{2}{|c|}{ Perabotan rumahtangga } \\
\hline \multicolumn{4}{|c|}{ Sumber : Data Primer Yang Diolah, 2016.} \\
\hline \multicolumn{2}{|c|}{$\begin{array}{l}\text { dan memiliki peranan penting yang } \\
\text { dimiliki oleh rumahtangga petani di desa } \\
\text { Mantangai Hilir. Peran tersebut sungguh } \\
\text { terasa ketika ada akses kepemilikan dan } \\
\text { akses manfaat. Akses kepemilikan dan } \\
\text { akses manfaat diatur dalam sistem }\end{array}$} & \multicolumn{2}{|c|}{$\begin{array}{l}\text { Mantangai Hilir dapat diklasifikasikan } \\
\text { menjadi tiga yakni, lahan milik pribadi, } \\
\text { lahan milik pemerintah desa, lahan milik } \\
\text { pemerintah. Struktur kepemilikan lahan di } \\
\text { desa Mantangai Hilir dapat dilihat pada } \\
\text { Tabel } 2 \text {. }\end{array}$} \\
\hline \multicolumn{4}{|c|}{ Tabel 2. Pemanfaatan Lahan dan Struktur kepemilikan di Desa Mantangai Hilir } \\
\hline $\begin{array}{c}\text { Pemanfaatan } \\
\text { Lahan }\end{array}$ & Pemilik & Penggarap & Pengalihan Akses \\
\hline $\begin{array}{l}\text { Perkebunan } \\
\text { Karet/Kelapa Sawit }\end{array}$ & Petani/Perusahaan & Petani/Perusahaan & $\begin{array}{l}\text { Pewarisan/pengalihan } \\
\text { antar } \\
\text { penggarap/penjualan }\end{array}$ \\
\hline Sawah/Ladang & $\begin{array}{l}\text { Petani/Kelompok } \\
\text { Tani/Gapoktan }\end{array}$ & $\begin{array}{l}\text { Petani/Kelompok } \\
\text { Tani/Gapoktan }\end{array}$ & $\begin{array}{l}\text { Pewarisan/Penjualan/ } \\
\text { Penyewaan }\end{array}$ \\
\hline $\begin{array}{l}\text { Pekarangan/ Kebun } \\
\text { Lainnya }\end{array}$ & Petani & Petani & Pewarisan/Penjualan \\
\hline Tanah Desa & Pemerintah Desa & $\begin{array}{l}\text { Pemerintah } \\
\text { Desa/Penyewa }\end{array}$ & $\begin{array}{l}\text { Peralihan Jabatan/ } \\
\text { Penyewaan }\end{array}$ \\
\hline Lahan Hutan & Perhutani & Perhutani/Petani & $\begin{array}{l}\text { Pengalihan antar } \\
\text { penggarap }\end{array}$ \\
\hline Lahan Sungai & Umum & Petani/nelayan & $\begin{array}{l}1 \\
-\end{array}$ \\
\hline
\end{tabular}

Sumber : Data Primer Yang Diolah, 2016. 
Penggunaan sumberdaya alam lokal yang digunakan sebagai sumber nafkah penting bagi rumahtangga petani di desa Mantangai Hilir adalah bersumber dari hasil perkebunan karet, sawah/ladang, pekarangan, dan hasil kebun lainnya, hasil hutan, serta hasil lahan rawa dan sungai. Sumberdaya ini dianggap penting oleh petani karena digunakan untuk kegiatan pertanian dan sumber ekonomi rumahtangga petani.

\subsubsection{Perkebunan Karet}

Produksi karet di wilayah ini masih merupakan komoditas unggulan disamping elapa, kelapa sawit dan kopi. Luas areal tanaman perkebunan adalah seluas 6.504 ha, dengan produksi 2.250 ton. Ketika perkebunan karet telah resmi menjadi milik rumahtangga petani, maka petani akan mengelola perkebunannya sebagai sumber pendapatan rumahtangga. Pengelolaan kebun karet diajarkan dan diwariskan secara turun-temurun kepada anggota keluarga atau anak. Perkebunan karet dapat dialihkan pengelolaannya kepada orang lain melalui pewarisan, penjualan atau penyewaan. Penjualan perkebunan hanya dilakukan ketika rumahtangga ada keperluan yang sangat mendesak.

Bagi rumahtangga petani yang memiliki kebun yang luas serta tidak mampu untuk mengelola kebun sendiri, akan menyewakan perkebunannya kepada petani lain yang tidak memiliki kebun karet. Terdapat perjanjian atau kesepakatan antara pemilik perkebunan dan penyewa. Pemilik perkebunan dan penyewa akan menyepakati berapa luas pohon karet yang dikelola dengan sistem bagi hasil. Sementara pewarisan akan dilakukan ketika kepala keluarga (orang tua) sudah tidak mampu lagi secara produktif untuk bekerja pada kebun karet miliknya dan membagikan perkebunan karet tersebut secara merata kepada pewaris atau anakanaknya.

\subsubsection{Sawah/Ladang}

Wilayah kabupaten Kapuas sebagian besar berupa kawasan lahan gambut dan lahan pasang surut, telah sejak lama menjadi areal pertanaman padi dan menjadi lumbung beras bagi daerah Provinsi Kalimantan Tengah (Dinas Pertanian, 2016). Potensi lahan di desa Mantangai Hilir pun juga sejalan dengan pendapat Oemar (2003) yakni terdiri dari lahan basah yang sebagian besar adalah lahan pasang surut dan bergambut serta sebagian lagi adalah lahan rawa lebak dan tadah hujan juga dijadikan sebagai areal pertanaman padi.

$$
\text { Sawah/ladang menghasilkan }
$$

komoditas primer berupa padi yang sangat penting bagi rumahtangga petani di desa Mantangai Hilir. Rumahtangga petani 
menempatkan komoditas beras sebagai kebutuhan pokok dalam pemenuhan kebutuhan hidup sehari-hari dan aktivitasaktivitas besar lainnya dalam kehidupan masyarakat di desa Mantangai Hilir.

Kepemilikan lahan sawah/ladang bervariasi antar rumahtangga. Data dari informan yang diwawancarai desa Mantangai Hilir rata-rata memiliki lahan sawah/ladang berkisar antara 8-70 borong atau jika dikonversikan berkisar antara 0,25-2 hektar. Penggarapan lahan sawah/ladang dilakukan oleh rumahtangga dengan menggunakan tenagakerja baik tenaga kerja dalam keluarga maupun tenaga kerja luar keluarga. Lahan sawah/ladang dapat dialihkan penggarapannya kepada orang lain melalui pewarisan, penyewaan atau penjualan. Penjualan lahan hanya dilakukan apabila ada keperluan yang sangat mendesak, sedangkan pewarisan dilakukan jika pemilik sudah tidak mampu untuk mengelola sendiri.

\subsubsection{Pekarangan dan Kebun Lainnya}

Rumahtangga petani di desa Mantangai Hilir memiliki lahan pekarangan yang dimanfaatkan untuk menanam berbagai jenis tanaman yang digunakan untuk memenuhi konsumsi rumahtangga sehari-hari serta sebagai sumber tambahan pendapatan. Lahan pekarangan umumnya ditanami tanaman mulai dari jenis sayur-sayuran, buahbuahan, dan tanaman obat-obatan sebagai apotik hidup, serta tanaman hias. Beberapa rumahtangga petani juga ada yang membuat jaring yang dijadikan kandang dan kolam kecil disekitar kebun untuk memelihara ternak dan ikan.

Beberapa rumahtangga petani juga memiliki kebun yang ditanam untuk buahbuahan yang letaknya ada yang terpisah dari rumah seperti rambutan, mangga, pisang, nangka, nenas, jambu biji, sirsak dan sawo, dengan luasan rata-rata antara 8-35 borong. Tambahan pendapatan yang dijadikan sebagai sumber nafkah tersebut diperoleh dari hasil pekarangan, juga berasal dari hasil kebun yang dipadukan dengan ternak dan ikan.

\subsubsection{Lahan Hutan}

Hutan dapat dimanfaatkan oleh petani untuk mengambil hasil hutan. Hutan dapat dimanfaatkan oleh masyarakat atau petani untuk mencari kayu bakar, berburu hewan-hewan atau unggas liar yang dapat dijadikan sebagai lauk atau hewan peliharaan, sampai kepada penebangan pohon untuk dijadikan papan yang digunakan sebagai bahan bangunan rumah, kandang, dan pemanfaatan untuk membuat perahu dan peralatan rumahtangga. 


\subsubsection{Lahan Rawa dan Sungai}

Keberadaan lingkungan fisik yang ada seperti lahan rawa dan sungai, menyediakan sumberdaya alam yang langsung dapat diambil dan dimanfaatkan untuk kebutuhan hidup rumahtangga. Kekayaan alam yang terkandung dari sungai merupakan sumberdaya yang dapat dimanfaatkan oleh rumahtangga di desa Mantangai Hilir. Hasil tumbuhan liar yang berasal dari rawa yang disebut "purun" dapat dijadikan sebagai bahan pembuat anyaman tikar, bakul, topi, dan kerajinan lainnya. Hasil dari sungai seperti ikan juga dapat dijadikan sebagai konsumsi pangan bagi rumahtangga serta sumber tambahan pendapatan.

\subsection{Pola Strategi Nafkah Rumahtangga}

\begin{tabular}{lcr}
\multicolumn{2}{c}{ Strategi nafkah } & \multicolumn{2}{c}{ rumahtangga } \\
merupakan & serangkaian & upaya yang \\
dilakukan & dengan & memanfaatkan \\
sumberdaya & yang dimiliki serta
\end{tabular}
sumberdaya yang tersedia di lingkungan sekitar. Aktivitas sumber nafkah dilakukan oleh rumahtangga di desa Mantangai Hilir sebagai dasar untuk membangun modal yang dibutuhkan oleh rumahtangga untuk tujuan pendapatan dan kesejahteraan rumahtangga. Istilah modal digunakan untuk menunjukkan sumberdaya yang dimiliki dan yang tersedia untuk diakses oleh rumahtangga.

$$
\text { Pola strategi nafkah dalam }
$$

pemanfaatan sumberdaya alam lokal di desa Mantangai Hilir secara tidak langsung juga menerapkan prinsip efisiensi biaya. Efisiensi biaya dilakukan oleh rumahtangga agar aktivitas yang mebutuhkan biaya produksi dilakukan seimbang dengan hasil yang diperoleh. Efisiensi biaya produksi dilakukan dalam tiga cara yakni (1) mengurangi penggunaan sarana produksi yang dianggap mahal dan tinggi; (2) menghasilkan sendiri sarana produksi pertanian;

(3) penggunaan modal sosial untuk mendapatkan sarana produksi secara gratis.

Strategi yang dilakukan oleh petani untuk mengurangi biaya produksi misalnya untuk lahan kebun dipupuk dengan menggunakan seresah-seresah daun, batang, dan dahan tanaman sebagai pupuk organik, penggunaan kotoran hewan peliharaan yang dijadikan sebagai pupuk. Strategi penyediaan bibit diperoleh dari pemanfaatan hasil panen sebelumnya, atau pun dari bibit/tunas anakan produktif hasil kebun sebelumnya. Strategi lainnya yakni dengan cara menanam tanaman dalam satu luasan lahan (usahatani campuran) dengan berbagai umur panen yang berbeda. Cara ini dimaksud untuk mengurangi resiko pertanian. Rumahtangga petani di desa Mantangai Hilir rata-rata memilih tanaman yang biasa dipanen dan sudah 
menghasilkan, tidak rumit, serta laku untuk dipasarkan, daripada menanam tanaman baru yang belum pasti menghasilkan keuntungan. Strategi nafkah rumahtangga di desa Mantangai Hilir disajikan pada Gambar 1.

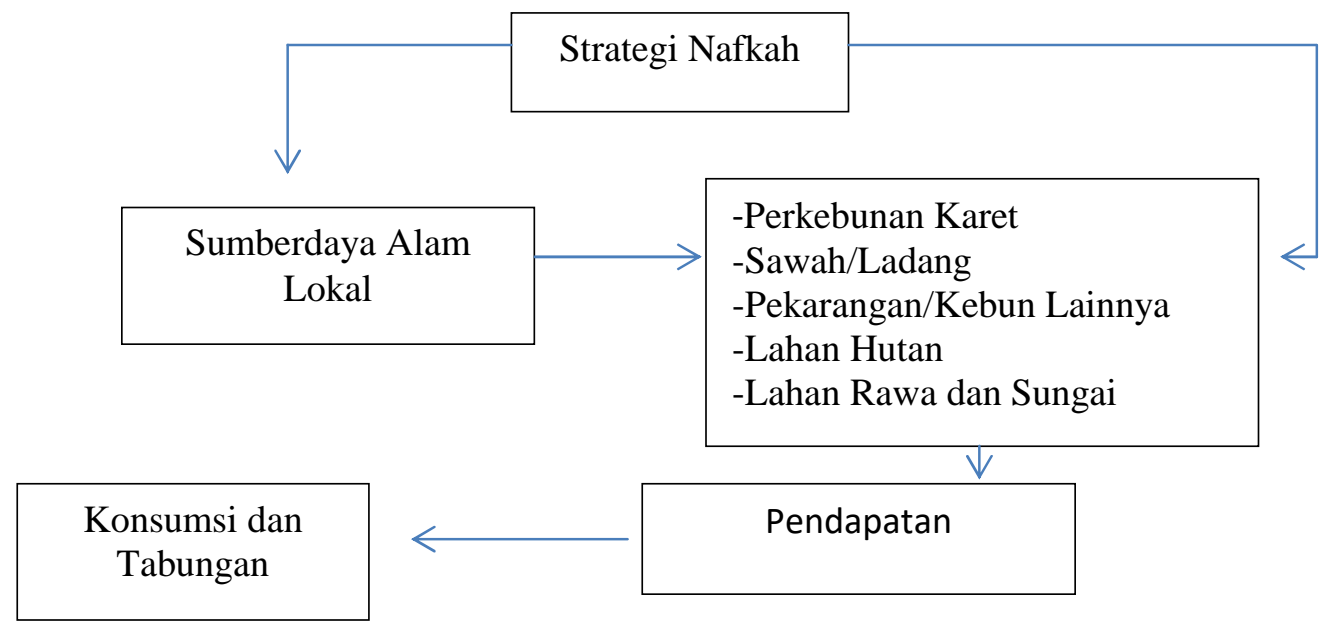

Gambar 1. Strategi Nafkah Rumahtangga di Desa Mantangai Hilir

Aktivitas untuk mencari nafkah merupakan bagian dari strategi nafkah rumahtangga sebagai pilihan-pilihan tindakan ekonomi yang dilakukan oleh rumahtangga untuk mencapai tujuan yakni pendapatan dan kesejahteraan rumahtangga.

\section{KESIMPULAN DAN SARAN}

Memahami kehidupan ekonomi rumahtangga petani di pedesaan, dapat didekati dengan menggunakan pola strategi nafkah (livelihood strategies).

Penggunaan sumberdaya alam lokal yang digunakan sebagai sumber nafkah penting bagi rumahtangga petani di desa Mantangai Hilir bersumber dari hasil perkebunan karet, sawah/ladang, pekarangan, dan hasil kebun lainnya, hasil hutan, serta hasil lahan rawa dan sungai. Sumberdaya ini dianggap penting oleh petani karena digunakan untuk kegiatan pertanian dan sumber ekonomi rumahtangga petani.

Pola strategi nafkah dalam pemanfaatan sumberdaya alam lokal di desa Mantangai Hilir secara tidak langsung menerapkan prinsip efisiensi biaya dimana pola strategi nafkah tersebut didasarkan atas pertimbangan rasionalitas keputusan rumahtangga petani. Rumahtangga petani dapat menentukan pilihan tindakan ekonomi untuk mencapai tujuan yakni 
Yuni Erlina

pendapatan dan kesejahteraan

rumahtangga.

\section{DAFTAR PUSTAKA}

Badan Pusat Statistik, 2017. Kapuas Dalam Angka 2016. ISSN : 0215-6830. Badan Pusat Statistik Kabupaten Kapuas. Kalimantan Tengah.

Ellis, Frank., 2000. Rural Livelihoods and Diversityin Developing. Oxford University Press. New York.

Gardner, B. L., and Gordon C., Rausser, 2001. Handbook of Agricultural Economics. Elsevier. AmsterdamLondon-New York-Oxford-ParisShannon-Tokyo.

Iqbal, Moch., 2004. Strategi Nafkah Rumahtangga Nelayan: Studi Kasus di dua Desa Nelayan Tangkap Kabupaten Lamongan Jawa Timur (Tesis). Sekolah Pascasarjana Institut Pertanian Bogor.

Mendola, M., 2007. Farm Household Production Theorities: A Review
Pola Strategi Nafkah Rumah Tangga Petani Berbasis Sumberdaya Lokal

Di Desa Mantangai Hilir Kecamatan Mantangai

of Institusional and Behavioral Response. Asian Development Review; Vol.24 No.1 page 49-68.

Mubyarto, 1989. Pengantar Ekonomi Pertanian. Lembaga Penelitian, Pendidikan dan Penerangan Ekonomi dan Sosial. Jakarta.

Pramutoko Bayu, 2012. Ekonomi Mikro: Pengantar Ilmu Ekonomi 1. Penerbit Jendela Pustaka Utama. Surabaya.

Sugiyono, 2015. Metode Penelitian Kuantitatif Kualitatif dan R \& D. Penerbit Alfabeta. Bandung.

Sukirno, Sadono., 2013. Mikroekonomi (Teori Pengantar). Edisi Ketiga. PT. Raja Grafindo Persada. Jakarta.

Widodo, Slamet., 2011. Strategi Nafkah Berkelanjutan Bagi Rumah Tangga Miskin di Daerah Pesisir. Makara Sosial Humaniora. BangkalanIndonesia. Vol.15, No.1:hal.1025. 